\title{
STRATEGI BADAN PELAYANAN PAJAK DAERAH KOTA MALANG DALAM MENGURAI TUNGGAKAN PAJAK BUMI BANGUNAN (PBB)
}

\author{
M. N. Romi. A.S dan Dewi Citra Larasati \\ Program Studi Ilmu Komunikasi, FISIP, Universitas Tribhuwana Tunggadewi \\ Jl. Telaga Warna Blok C, Tlogomas, Kec. Lowokwaru, Kota Malang. \\ E-mail : romijasujan@gmail.com
}

\begin{abstract}
Land and Building in Indonesia are worned taxes regional. This tax as called $P B B$ is one of the taxes transferred from the Central Government to the Local Government. The government of Malang City has made program of PBB at the beginning of the year in 2013. Authority about $P B B$ are delegated to institution BP2D. BP2D are affording receivable amount Rp.110.348.875.252,- from PBB. The researcher has interestingabout strategic this institution to increase income from $P B B$. This research use desciptive qualitative approach. The outcome from this research are 1) BP2D often held a tax socialization, 2) The institution cooperating with stakeholders, 3) BP2D were establisinga unit to enforce taxes. This unit as called OPGAB, 5) The official are mapping about economic ability, 6) Implementation of a program was called Sunset Policy, 7) operate the tax car, and 8) Institution giving rewards totaxpayers who have good payment.
\end{abstract}

Keywords: Local Tax, Building Land Tax (PBB), Local Government

Abstrak: Pajak Bumi Bangunan (PBB) Perkotaan merupakan salah satu pajak hasil pelimpahan dari Pemerintah Pusat kepada Pemerintah Daerah. Hal ini tertuang dalam Undang-Undang Nomor 28 Tahun 2009 tentang Pajak Daerah dan Retribusi Daerah. Berdasarkan Berita Acara Serah Terima (BAST) pada tahun 2013, Kota Malang mendapatkan piutang PBB sebesar Rp.110.348.875.252,-. Sehingga Badan Pelayanan Pajak Daerah (BP2D) Kota Malang perlu menjalankan beberapa strategi dalam mengurai tunggakan PBB Perkotaan hasil pelimpahan dari Pemerintah Pusat. Penelitian ini menggunakan pendekatan deskriptif kualitatif, dimana diperoleh hasil bahwa dalam BP2D melakukan 7 strategi yaitu1) Menggelar beragam sosialisasi sadar pajak, 2) Melakukan kerjasama dengan berbagai pihak, 3) Membentuk Satgas Peningkatan Pajak Daerah dan melakukan menggalakan Operasi Gabungan (OPGAB), 4) Melakukan pemetaan yang biasa dikenal dengan sebutan Cleansing dan Sensus, 5) Pelaksanaan program Sunset Policy, 6) Mobil Pajak keliling multifungsi, dan 7) pemberian reward bagi Wajib Pajak yang sudah membayar.

Abstrak: Pajak Daerah, Pajak Bumi dan Bangunan, Pemerintah Daerah

\section{PENDAHULUAN}

Desentralisasi merupakan jembatan bagi pemerintah daerah untuk dapat membangun rumah tangganya sendiri serta mendekatkan pemerintah kepada rakyat. Menurut Domai (2011:2), Desentralisasi sangat penting dalam hubungan antar pemerintahan karena tidak mengurangi relevansi pemerintahan pusat, justru memberikan kadar otonomi yang jelas bagi institusi melalui struktur pemerintah atau pemerintah daerah dan memudahkan partisipasi dalam urusan pekerjaan melalui beragam hubungan antar 
pemerintah". Pemerintah pusat tidak mungkin dapat menjalankan semua tugas pokok dan fungsi serta kekuasaannya sampai pada pemerintahan level bawah.Atasdasarpertimbangan tersebut, maka pemerintahan daerah diberikan kewenangan yang luas, nyata dan bertanggungjawab sehingga memberi peluang kepada daerah agar leluasa mengatur dan melaksanakan kewenangannya sesuai dengan prakarsanya sendiri sesuai dengan kepentingan masyarakat setempat dan potensi setiap daerah dalam meningkatkan Pendapatan Asli Daerah (PAD), istilah itulah yang disebut dengan desentralisasi fiskal. Menurut Larasati (2017) Desentralisasi fiskal, mengunggulkan pajak sebagai salah satu sumber penerimaan penting yang digunakan sebagai sumber pembiayaan dalam menyelenggarakan roda pemerintahan. Hal ini, diperkuat dengan diberlakukannya UndangUndang Nomor 28 tahun 2009 tentang Pajak Daerah dan Retribusi Daerah (UU PDRD) PBB-P2. Dijelaskan dalam Undang-Undang PDRD pasal 182 ayat 1, bahwa kewenangan pemungutan PBB-P2 dialihkan kepada masing-masing Pemerintah Daerah di seluruh Indonesia dengan batas waktu 1 Januari 2014.

Pajak Bumi Bangunan (PBB) Perkotaan merupakan salah satu pajak hasil pelimpahan dari Pemerintah Pusat kepada Pemerintah Daerah. Hal ini tertuang dalam Undang-Undang Nomor 28 Tahun 2009 tentang Pajak Daerah dan Retribusi Daerah. Berdasarkan Berita Acara Serah Terima (BAST) pada tahun 2013, Kota Malang mendapatkan piutang PBB sebesar Rp.110.348.875.252,-. (Sumber : Badan Pelayanan Pajak Daerah Kota Malang, 2018

Piutang PBB tersebut diakibatkan karena beberapa hal seperti kelalain dan keterlambatan dari wajib pajak yang tidak membayar tepat waktu sehingga terjadi penunggakan PBB. Dimana ketika terjadi keterlambatan pembayaran akan dikenai sangsi 2 persen perbulan. Hal ini akan menimbulkan tagihan yang sangat besar jika tidak segera dibayarkan.

Oleh karena itu, Penelitian ini bertujuan untuk Pertama, mengetahui Strategi Badan Pelayanan Pajak Daerah Kota Malang dalam mengurai tunggakan PBB Perkotaan; Kedua, untuk mengidentifikasi Permasalahan yang dihadapi oleh Badan Pelayanan Pajak Daerah Kota Malang dalam menjalankan strategi mengurai tunggakan PBB Perkotaan.

\section{KAJIAN LITERATUR \\ Strategi}

Strategi sebenarnya diawali dari dan populer di lingkungan militer. Secara etimologi, Sedarmayanti, (2016:115) menjelaskan bahwa strategi sebagai teknik dan taktik dapat diartikan pula sebagai kiat.Strategi dalam manajemen berarti kiat atau cara dan taktik utama yang dirancang secara sistematis dalam melaksanakan fungsi manajemen, terarah pada tujuan strategi organisasi. Menurut Sedarmayanti (2016:44) strategi adalah rencana jangka panjang perusahaan mengenai bagaimana perusahaan akan menyeimbangkan kekuatan dan kelemahan, kesempatan eksternal dan ancaman yang dihadapi untuk menjaga keuntungan kompetitif. Sedangkan kumpulan keputusan dan tindakan yang menghasilkan perumusan dan penerapan strategi, di desain untuk mencapai sasaran organisasi disebut sebagai manajemen strategis (Pearce dan Robinson dalam Sedarmayanti, 2016:46)

\section{Manajemen Sumber Daya Manusia (MSDM)}

Menurut Hasibuan (2012:10) dalam bukunya "Manajemen Sumber Daya Manusia" menyatakan bahwa Manajemen sumber daya manusia adalah ilmu atau seni mengatur 


\section{REFORMASI}

ISSN 2088-7469 (Paper) ISSN 2407-6864 (Online)

Volume 8 Nomor 2 (2018)

hubungan dan peranan tenaga kerja/pegawai agar efektif dan efisien dalam mewujudkan tujuan dari organisasi.

Adapun hal-hal yang perlu mendapat perhatian dari organisasi pemerintah atau swasta dalam Manajemen Sumber Daya Manusia adalah sebagai berikut:

1. Ketersediaan Sumber Daya Manusia;

2. Kemampuan Sumber Daya Manusia;

3. Profesionalisme Sumber Daya Manusia.

\section{Pajak Daerah}

Berdasarkan Undang-Undang Republik Indonesia Nomor 28 Tahun 2009 tentang perubahan atas Undang-Undang Republik Indonesia Nomor 34 Tahun 2000 Tentang Pajak Daerah dan Retribusi Daerah, pajak daerah adalah:

"Iuran wajib pajak yang dilakukan oleh orang pribadi atau badan kepala daerah tanpa imbalan langsung yang seimbang yang dapat dipaksakan berdasarkan peraturan perundang-undangan yang berlaku, yang digunakan untuk membiayai penyelenggaraan pemerintah daerah dan pembangunan daerah".

\section{Peraturan Daerah tentang Pajak Daerah}

Undang-Undang Nomor 28 Tahun 2009 mengatur bahwa untuk dapat dipungut pada suatu daerah, setiap jenis pajak daerah harus ditetapkan dan tidak boleh bertentangan dengan kepentingan umum atau ketentuan perundang-undangan yang lebih tinggi. Dalam menyambut Undang-Undang Nomor 28 Tahun 2009, pemerintah Kota Malang telah menyiapkan Peraturan Daerah Kota Malang Nomor 16 Tahun 2010 tentang Pajak Daerah.

\section{Jenis-Jenis Pajak Daerah}

Jenis-jenis pajak daerah menurut Undang-Undang Nomor 28 Tahun 2009 terbagi menjadi dua yaitu pajak Provinsi dan pajak Kabupaten/Kota. Pembagian ini dilakukan sesuai dengan kewenangan pengenaan dan pemungutan masing-masing pajak daerah pada wilayah administrasi Provinsi atau Kabupaten/Kota yang bersangkutan. Berdasarkan Undang-Undang tersebut ditetapkan jenis-jenis pajak daerah, yaitu sebagai berikut:

1. Pajak Provinsi terdiri atas:
a. Pajak Kendaraan Bermotor;
b. Bea Balik Nama Kendaraan Bermotor;
c. Pajak Bahan Bakar Kendaraan Bermotor;
d. Pajak Air Permukaan; dan
e. Pajak Rokok.

2. Jenis Pajak Kabupaten/Kota terdiri atas:
a. Pajak Hotel;
b. Pajak Restoran;
c. Pajak Hiburan;
d. Pajak Reklame;
e. Pajak Penerangan Jalan;
f. Pajak Mineral Bukan Logam dan Batuan;
g. Pajak Parkir;
h. Pajak Air Tanah;
i. Pajak Sarang Burung Walet; 
j. Pajak Bumi dan Bangunan Pedesaan dan Perkotaan; dan

k. Bea Perolehan Hak atas Tanah dan Bangunan.

Berdasarkan pasal 185 UU No 28 Tahun 2009 tentang PDRD, maka sejak tanggal 1 Januari 2010, pemerintah Kabupaten/kota sudah diperbolehkan untuk menerima pengalihan PBB P2 dan BPHTB. Pengalihan pengelolaan Bea perolehan Hak atas Tanah dan Bangunan (BPHTB) dan Pajak Bumi Bangunan Pedesaan dan Perkotaan (PBB P2) dari pemerintah pusat kepada pemerintah daerah tersebut merupakan suatu bentuk tindak lanjut kebijakan otonomi daerah dan desentralisasi fiskal. Dengan pengalihan ini maka kegiatan proses pendataan, penilaian, penetapan, pengadministrasian, pemungutan/penagihan dan pelayanan PBB P2 akan diselenggarakan oleh pemerintah daerah (Kabupaten/Kota).

\section{Pajak Bumi Bangunan Pedesaan dan Perkotaan}

Pajak Bumi dan Bangunan (PBB) Pedesaan dan Perkotaan adalah pajak atas bumi dan atau bangunan yang dimiliki, dikuasai, dan atau dimanfaatkan oleh orang pribadi atau badan, kecuali kawasan yang digunakan untuk kegiatan usaha perkebunan, perhutanan, dan pertambangan.

\section{Dasar Hukum PBB}

Pemungutan PBB Pedesaan dan Perkotaan di Indonesia saat ini didasarkan pada dasar hukum yang jelas dan kuat, sehingga harus dipatuhi oleh masyarakat dan pihak yang terkait. Dasar hukum pemungutan PBB Pedesaan dan Perkotaan pada suatu Kabupaten/Kota adalah sebagai berikut:

1. Undang-Undang Nomor 28 Tahun 2009 tentang Pajak Daerah dan Retribusi Daerah

2. Peraturan Daerah Kota Malang Nomor 7 Tahun 2015 tentang Pajak Bumi dan Bangunan Perkotaan.

\section{Cara Pemungutan, Penetapan, dan Ketetapan PBB}

1. Pemungutan PBB Pedesaan dan Perkotaan

Pemungutan PBB Pedesaan dan Perkotaan tidak dapat diborongkan, artinya bahwa seluruh proses kegiatan pemungutan pajak tidak dapat diserahkan kepada pihak ketiga. Cara pemungutan PBB antara lain:

a. Percetakan formulir perpajakan;

b. Pengiriman surat kepada wajib pajak;

c. Penghimpunan data objek dan subjek pajak.

2. Penetapan PBB Pedesaan dan Perkotaan

Pada dasarnya sistem pemungutan pajak yang diterapkan dalam PBB Pedesaan dan Perkotaan adalah penetapan oleh kepala daerah. Penetapan pajak oleh kepala daerah diwujudkan dalam bentuk:

a. Penerbitan Surat Pemberitahuan Pajak Terutang (SPPT);

b. Surat Ketetapan Pajak Daerah (SKPD).

3. Ketetapan PBB Pedesaan dan Perkotaan

Ketetapan untuk wajib PBB Pedesaan dan Perkotaan sesuai dengan ketetapan kepala daerah maupun yang dibayar sendiri oleh wajib pajak, disampaikan melalui:

a. Surat Tagihan Pajak Daerah (STPD);

b. Surat Ketetapan Pajak Daerah Kurang Bayar (SKPDKB); 
c. Surat Ketetapan Pajak Daerah Kurang Bayar Tambahan (SKPDKBT); dan

d. Surat Ketetapan Pajak Daerah Nihil (SKPDN).

\section{Pembayaran dan Penagihan PBB Perdesaaan dan Perkotaan}

1. Pembayaran PBB Pedesaan dan Perkotaan terutang dilunasi dalamjangka waktu yang ditentukan dalam peraturan daerah, dengan memperhatikan:

a. Jangka waktu pembayaran pajak;

b. Tempat pembayaran pajak;

c. Angsuran pembayaran pajak;

d. Penundaan pembayaran pajak; dan

e. Sanksi atas keterlambatan pembayaran pajak.

2. Penagihan PBB Pedesaan dan Perkotaan

Apabila pajak yang terutang tidak dilunasi setelah jatuh tempo pembayaran maka kepala daerah atau pejabat yang ditunjuk akan melakukan tindakan penagihan pajak. Penagihan pajak dilakukan terhadap pajak terutang melalui:

a. Surat Pemberitahuan Pajak Terutang (SPPT);

b. Surat Ketetapan Pajak Daerah (SKPD);

c. Surat Keputusan Pembetulan (SKP);

d. Surat Keputusan Keberatan (SKK); dan

e. Putusan Banding yang menyebabkan jumlah pajak yang harus dibayar bertambah.

Apabila jumlah pajak terutang yang masih harus dibayar tidak dilunasi dalam jangka waktu yang ditentukan dalam surat teguran dan surat peringatan kepada wajib pajak, maka kepala daerah atau pejabat yang ditentukan akan melaksanakan penagihan seketika dan sekaligus memberitahukan Surat Paksa. Tindakan penagihan dengan Surat Paksa dapat dilanjutkan dengan tindakan:

a. Melaksanakan Penyitaan;

b. Melaksanakan Pelelangan;

c. Mengusikan Pencegahan;

d. Melaksanakan Penyaderaan; dan

e. Menjual barang yang telah disita.

Tindakan penagihan pajak dengan Surat Paksa dan penagihan pajak seketika dan sekaligus dalam pemungutan PBB Pedesaan dan Perkotaan dilakukan sesuai dengan ketentuan umum pajak daerah.

\section{METODE PENELITIAN}

Penelitian ini menggunakan metode penelitian kualitatif. Menurut Lofland dan Lofland dalam Moleong (2015:157) menjelaskan bahwa Penelitian kualitatif lebih peka dan dapat menyesuaikan diri dengan kondisi di lapangan, sehingga urutan kegiatan dapat berubah-ubah tergantung kondisi dan gejala-gejala yang ditemukan. Oleh sebab itu, sumber data utama dalam penelitian kualitatif ialah kata-kata dan tindakan, selebihnya adalah data tambahan seperti dokumen dan lain-lain yang peneliti dapatkan di Kantor Badan Pelayanan Pajak Daerah (BP2D) Kota Malang yang bertempat di Perkantoran Terpadu Gedung B, Jl. Mayjend Sungkono, Arjowinangun, Kedungkandang, Kota Malang, Jawa Timur 65132.

Berdasarkan cara memperoleh data yang diperlukan dalam penelitian ini, jenis data yang digunakan dibagi menjadi empat diantaranya yaitu : kata-kata dan Tindakan, Sumber Tertulis, Foto, dan data Statistik. Sedangkan untuk teknik pengumpulan data, penelitian ini 
menggunakan model trianguasi teknik, berarti peneliti menggunakan teknik pengumpulan data yang berbeda-beda untuk mendapatkan data dari sumber yang sama. Setelah memperoleh data, maka perlu adanya upaya yang dilakukan dengan cara bekerja dengan data, mengorganisasikan data, memilah-milahnya menjadi satuan yang dapat dikelola, mensintesiskannya, mencari dan menemukan pola, menemukan apa yang penting dan apa yang dipelajari, dan memutuskan apa yang dapat diceritakan kepada orang lain (Bogdan \& Biklen dalam Moleong (2015:248).

\section{HASIL DAN PEMBAHASAN}

\section{Strategi Badan Pelayanan Pajak Daerah Kota Malang dalam Mengurai Tunggakan PBB Perkotaan}

Melihat permasalahan tersebut di lapangan, BP2D Kota Malang mencoba untuk mencari strategi dengan beragam inovasi dalam meningkatkan kesadaran kepada wajib pajak.

Strategi pertama, dimulai dari menggelar beragam sosialisasi. Sosialisasi dilakukan dengan adanya kerjasama dengan media massa yang ada di Kota Malang. Semua program/kegiatan/kebijkan/event yang diselenggarakan oleh BP2D Kota Malang selalu diliput oleh media massa dari media cetak, elektronik hingga media online. Biasanya berbentuk press release, siaran di radio-radio lokal (City Guide 911 FM, Kosmonita) dan beberapa stasiun televisi lokal (JTV, Batu TV, Malang TV). Sosialisasipun juga dilakukan melalui media sosial, seperti : facebook, twitter, dan website resmi milik BP2D.

Bentuk strategi lainnya adalah sosialisasi dalam bentuk program edukasi. Diharapkan dengan adanya program edukasi ini, dapat memberikan pemahaman tentang kesadaran membayar pajak sejak dini. Sehingga anak-anak berani menyampaikan kepada orang tua dan masyarakat di lingkungan sekitarnya tentang pentingnya membayar pajak dan manfaat pajak terhadap pendidikan di Kota Malang. Bentuk sosialisasi tersebutsepertiTax Goes to School, Tax Goes to Campus danTax Goes to Mall.

Strategi kedua, melakukan kerjasama dengan berbagai pihak yaitu Polres Malang Kota, Kejaksaan Negeri Malang, Tim Auditor BPKP Perwakilan Jawa Timur, Kerjasama dengan Media Massa.

Kerjasama dengan Polres Malang Kota dilaksanakan dengan adanya penandatanganan kerjasama mengenai Operasi Sadar Pajak. Dengan adanya kerjasama tersebut, maka ketika BP2D melakukan operasi sadar pajak, maka Polres Kota Malang akan menurunkan anggotanya. Pertimbangan dari strategi yang dilaksanakan ini dikarenakan Polres Kota Malang memiliki Babinkamtibmas di 57 kelurahan. Babinkamtibmas diperlukan ketika BP2D Kota Malang melakukan sosialisasi perpajakan daerah. Dengan menggandeng Babinkamtibmas, maka warga akan banyak yang hadir dalam sosialisasi tersebut. Tidak dapat dipungkiri, di wilayah (kelurahan dan kecamatan) Babinkamtibmas begitu berpengaruh karena Babinkamtibmas sangat disegani di kelurahan maupun di kecamatannya masing-masing.

Selain melakukan MOU dengan Polres Kota Malang, BP2D juga melakukan penandatanganan MOU kerjasama lainnya dengan Kejaksaan Negeri Malang. Kejaksaan Negeri sengaja digandeng untuk menagih para wajib pajak yang membandel dalam memenuhi kewajibannya membayar pajak daerah. Ketika pemberitahuan dari BP2D tidak dipatuhi oleh Wajib Pajak (WP) maka akan ada penagihan paksa dan akan diproses 
menggunakan upaya non-ligitasi. Jika upaya non ligitasi tidak berhasil maka proses ligitasi dalam pengadilan perdata dilaksanakan.

BP2D juga merangkul Badan Pengawas Keuangan dan Pembangunan (BPKP) perwakilan Jawa Timur. Kerjasama dengan BPKP ini lebih pada peningkatan kapasitas pegawai BP2D Kota Malang. BPKP perwakilan Jawa Timur berperan dalam tiga hal yaitu memberikan modul pemeriksaan pajak, pendampingan pemeriksaan pajak, dan audit serta bimtek tentang pemeriksaan pajak. Diharapkan dengan kerjasama ini, akan dapat mengoptimalkan kerja para pegawai BP2D Kota Malang.

Strategi ketiga,Membentuk Satuan Petugas (Satgas) Peningkatan Pajak Daerah dan menggalakan Operasi Gabungan (OPGAB) Sadar Pajak bersama Badan Narkotika Nasional (BNN) Kota Malang, Kejaksaan Negeri, Polresta Malang, TNI, Satpol PP, Bagian Hukum dan media Massa.OPGAB ini dilakukan dengan menyasar ke tempat-tempat hiburan termasuk cafe dan karaoke yang tersebar di Kota Malang, juga memeriksa pembukuan para WP yang tergolong Pajak Hiburan, pajak reklame, pajak penerangan jalan, serta pajak bumi dan bangunan. Jika dalam OPGAB ditemui beberapa pelanggaran, langsung seketika diberikan tindakan tegasmulai sanksi ringan seperti teguran, penyetikeran (stiker segel, patok tax line), hingga digergaji oleh satgas sadar pajak.

Strategi keempat, yaitu dengan melakukan pemetaan yang biasa dikenal dengan sebutan Cleansing dan Sensus. Cleansing dan sensus yang mana kegiatan ini berupa identifikasi kasus dan penyusunan database Wajib Pajak yang memiliki tunggakan PBB. Petugas BP2D bersama pihak ketiga akan mendatangi dan mengidentifikasi langsung kasus di lokasi Wajib Pajak. Untuk mengetahui validitas data tunggakan Wajib Pajak di lapangan.

Strategi kelima, adalah pelaksanaan Sunset Policy. Sunset Policy merupakan penghapusan sanksi administrasi atau denda atas keterlambatan pelunasan PBB yang belum terbayar dalam rentang waktu antara tahun 1994 sampai dengan tahun 2012. Mengacu pada Perwal Nomor 7 Tahun 2016 tentang Penghapusan Sanksi Administratif atas Keterlambatan Pembayaran Pajak Bumi dan Bangunan Perkotaan untuk Masa Pajak sampai dengan tahun 2012, Program ini sudah berjalan selama 2 tahap, tahap pertama (Jilid pertama) di launching secara resmi oleh Walikota Malang Bapak H. Mochamad Anton pada tanggal 17 Agustus 2016 dan berakhir pada tanggal 31 Oktober 2016, dengan menunai sukses yang sangat luar biasa. Dari target RP 1 Milyar, pengajuan terkumpul mencapai Rp 1, 591 Milyar dari 1213 objek pajak pada hari penutupan. Sunset Policy jilid kedua pada 16 Januari 2017. Bertajuk "Sunset Policy II", program ini berjalan hingga 16 April 2017. Selama tiga bulan berjalan tercatat 539 wajib pajak (WP) yang memanfaatkan program tersebut, dengan total nominal yang terkumpul senilai Rp 587,2 juta. Jika dikumulatifkan selama dua kali penyelenggaraan Sunset Policy pada 2016 dan 2017, pengajuan terkumpul mencapai Rp 2,18 Milyar dari 1.752 wajib pajak (WP).

Strategi keenam, Adanya mobil tax keliling multifungsi. Mobil ini sengaja di desain supaya lebih fleksibel dan melayani wajib pajak di pusat-pusat keramaian. Biasanya mobil ini, di parkir di area pusat perbelanjaan seperti Malang Town Square (MATOS), Mall Olimpic Garden (MOG) atau Plaza Araya. Mobil pelayanan pajak ini mulai di operasikan sejak Januari 2017.

Selain sebagai mobil pelayanan pajak, mobil ini juga berperan sebagai ujung tombak suluh penerangan terkait perpajakan daerah. Masyarakat yang ingin mendapatkan edukasi singkat mengenai perpajakan daerah bisa menyimak video yang di putar di mobil multifungsi sembari mendengarkan penjelasan dari petugas. 
Warga yang ingin mobil ini hadir di kampung atau di lingkungan tempatnya tinggal saat ada kegiatan warga, bisa langsung mengajukan permohonan ke BP2D. Sehingga warga bisa mendapatkan kemudahan fasilitas membayar on the spot, edukasi perpajakan daerah dan menikmati fasilitas hiburan gratis (karena mobil ini juga dilengkapi dengan fasilitas karaoke).

Strategi ketujuh, BP2D juga memberikan reward kepada WP yang telah membayar lunas PBB, berupa pemberian sembako, diskon wisata, souvenir berlogo Bank Jatim, dan kupon belanja. Hal ini dilakukan selain untuk meningkatkan pelayanan juga bertujuan untuk menarik minat WP untuk segera membayar tepat waktu, serta dapat mendekatkan pelayanan kepada WP.

Kegiatan reward yang rutin dilakukan setiap tahunnya adalah Jalan Sehat Sadar Pajak berhadiah utama mobil dan ratusan hadiah hiburan lainnya yang tidak kalah menarik. Jalan sehat ini dikemas dalam bentuk yang menarik, entertainment panggung hiburan mendatangkan artis ibukota dan hiburan lainnya yang dapat menarik minat masyarakat. Bukti lunas PBB bisa ditukarkan dengan kupon untuk diundi saat puncak acara.

Reward lainnya adalah dengan melunasi tagihan PBB maka akan mendapatkan potongan harga lima puluh persen untuk tiket masuk Hawai Water Park. Tidak hanya reward di pusat rekreasi, BP2D juga bekerjasama dengan Asosiasi Pengelola Pusat Belanja Indonesia (APPBI) DPC Malang. Dengan menunjukkan bukti pelunasan PBB di acara Malang Raya Great Sale, maka wajib pajak akan mendapatkan bonus tiga kupon undian hadiah mendapatkan hadiah tambahan lainnya.Reward juga diberikan kepada Wajib Pajak yang membayar PBB saat acara blusukan Abah Anton ke Kelurahan yang diadakan setiap dua minggu sekali dengan memberikan paket Sembako.

Ketujuh strategi yang telah dilaksanakan oleh Badan Pelayanan Pajak Daerah (BP2D) Kota Malang telah memberikan hasil yang sangat signifikan terhadap realisasi PBB di Kota Malang selama lima tahun terakhir. PBB yang di targetkan setiap tahun, dalam realisasinya selalui melampaui target. Hal ini dapat dilihat dari tabel berikut ini :

Tabel 1. Target dan Realisasi PBB Kota Malang dalam 5 Tahun Terakhir

\begin{tabular}{|c|c|c|}
\hline THN & TARGET & REALISASI \\
\hline 2013 & 45.651 .921 .983 & 47.843 .891 .288 \\
\hline 2014 & 53.869 .267 .940 & 53.881 .514 .370 \\
\hline 2015 & 53.869 .267 .940 & 58.614 .789 .726 \\
\hline 2016 & 56.869 .268 .000 & 62.416 .413 .408 \\
\hline 2017 & 56.869 .268 .000 & 58.598 .970 .147 \\
\hline
\end{tabular}

Sumber : BP2D Kota Malang, Mei 2018

\section{Permasalahan yang Dihadapi oleh Badan Pelayanan Pajak Daerah Kota Malang dalam Menjalankan Strategi Mengurai Tunggakan PBB Perkotaan.}

Dalam menjalankan strategi untuk mengurai tunggakan PBB Perkotaan, BP2D juga dihadapkan dengan berbagai permasalahan, baik permasalahan internal maupun permasalahan eksternal. Permasalahan internal adalah situasi internal BP2D yang berupa kompetensi/Kapabilitas/Sumberdaya yang dimiliki. Sedangkan permasalahan eksternal adalah situasi eksternal BP2D yang berpotensi menimbulkan kesulitan.

Permasalahan internal yang dihadapi oleh BP2D adalah masalah sumber daya manusia (SDM) tersebut diantaranya kurangnya kemampuan Sumber Daya Manusia atau 


\section{REFORMASI}

ISSN 2088-7469 (Paper) ISSN 2407-6864 (Online)

Volume 8 Nomor 2 (2018)

pegawai BP2D dalam menguasai Teknologi informasi, sehingga sangat berpengaruh terhadap mutu pelayanan terhadap masyarakat atau Wajib Pajak (WP). Ini dikarenakan masih minimnya tingkat pendidikan para pegawai BP2D. Hal ini bisa dilihat berdasarkan data yang diperoleh peneliti di BP2D Kota Malang pada gambar berikut ini :

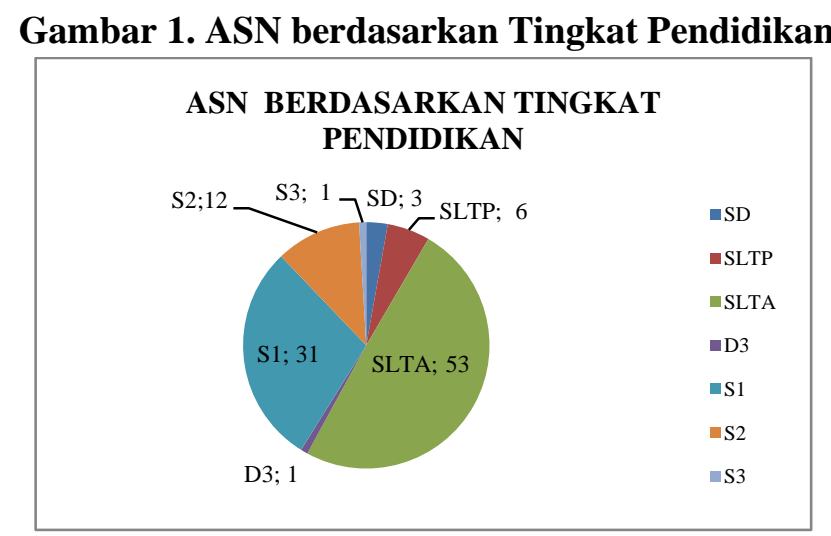

Sumber : BP2D Kota Malang, Juni 2018

Dari diagram Aparatur Sipil Negara (ASN) yang ada di BP2D Kota Malang sebagian besar masih berpendidikan SMA. Sehingga hal ini sangat berpengaruh terhadap profesionalisme sumber daya manusia atau pegawai Badan Pelayanan Pajak Daerah dalam melaksanakan pekerjaan. Semakin tinggi tingkat pendidikan pegawai, maka akan semakin luas pengetahuan dan wawasan pegawai. Sebaliknya, jika tingkat pendidikan pegawai rendah akan menyempitkan cara berfikir dan cara pandang seseorang. Sehingga akan dapat mempengaruhi kinerjanya.

Setiap organisasi pada masa sekarang, menuntut pegawainya untuk profesional. Karena tuntutan zaman menuntut segala sesuatu yang praktis dan serba online. Tuntutan zaman tersebut, belum mampu dipenuhi oleh pegawai BP2D Kota Malang. Terutama kemampuan pegawai dan keahlian khusus dibidang teknologi informasi. Untuk mengatasi permasalahan tersebut, BP2D Kota Malang mencoba untuk membekali pegawainya dengan pelatihan-pelatihan dalam bentuk diklat, baik yang diadakan di kantor (on the job trainning) atau diklat yang diadakan di luar kantor (off the job trainning) dengan mendatangkan trainner.

Selain itu, untuk mengatasi permasalahan rendahnya tingkat pendidikan pegawai di BP2D sertauntuk membantu meningkatkan ritme pelayanan di BP2D kepada masyarakat maka secara internal BP2D melakukan rekruitmen tenaga bantu.Berdasarkan data di Bagian Tata Usaha, terdapat63 orang tenaga bantu di Badan Pelayanan Pajak Daerah yang tergambar sebagaimanadiagram di bawah ini :

Gambar 2 Jumlah Tenaga Bantu di BP2D Kota Malang berdasarkan Jenis Kelamin 


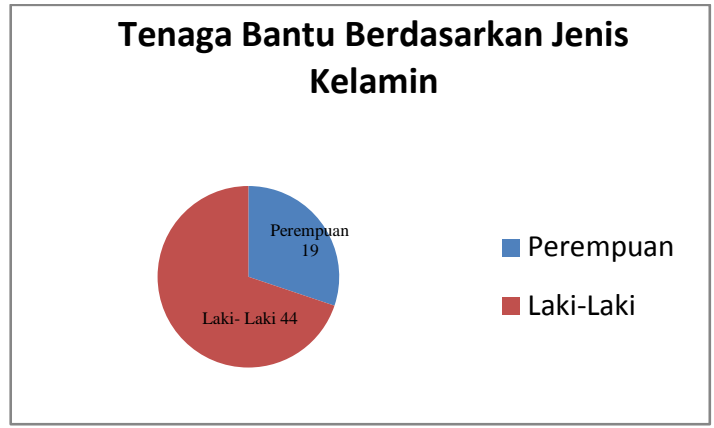

Sumber : BP2D Kota Malang, Juni 2018

Ternyata dalam pelaksanaannya di lapangan, perekruitan tenaga bantu tersebut, menimbulkan masalah baru karena rendahnya kemauan dari pegawai untuk belajar. Walaupun sudah diberikan pelatihan, pegawai atau tenaga bantu tersebut belum bisa menguasai pekerjaan secara optimal. Oleh karena itu, diharapkan peran pemimpin lebih memotivasi pegawai BP2D untuk lebih meningkatkan semangat dalam kemauan belajar, dengan memberikan reward dan punishment terhadap pegawai sehingga dapat memberikan pelayanan yang optimal terhadap masyarakat atau wajib Pajak.

Selain permasalahan internal, Badan Pelayanan Pajak Daerah (BP2D) juga menghadapipermasalahan eksternal dalam menjalankan beberapa strategi dalam mengurai tunggakan Pajak Bumi dan Bangunan (PBB) Perkotaan. Dimana masih terdapat wajib pajak yang tidak patuh dan kurang menyadari kewajibannya dalam membayar pajak. Sehingga jumlah tunggakan atau piutang Pajak Bumi dan Bangunan Kota Malang selalu mengalami peningkatan tiap tahunnya. Selain itu, ketidakpastian kondisi ekonomi wajib pajak, juga memberikan dampak pada keterlambatan WP dalam melakukan pembayaran.

\section{KESIMPULAN}

StrategiBadanPelayananPajak Daerah Kota Malang dalammenguraitunggakanPBB Perkotaanadalahyaitu :

1) Melakukanberagamsosialisasi sadar pajak baik di kelurahan, sekolah, kampus, dan mall,

2) Melakukan kerjasama dengan berbagai pihak,

3) Membentuk Satgas Peningkatan Pajak Daerah dan melakukan menggalakanOperasiGabungan (OPGAB),

4) MelakukanpemetaanCleansingdanSensus,

5) Pelaksanaan Sunset Policy,

6) Mengoperasikan mobil tax keliling, dan

7) pemberian reward bagi Wajib Pajak yang sudah membayar.

Sedangkan permasalahan yang dihadapi oleh Badan Pelayanan Pajak Daerah Kota Malang dalam menjalankan strategi mengurai tunggakan PBB perkotaan terdiri dari permasalahan internal yaituminimnya tingkat pendidikan para pegawai BP2D. Dan permasalahan eksternal yaitu masih terdapat wajib pajak yang tidak patuh dan kurang menyadari kewajibannya dalam membayar pajak. Maka dapat dirumuskan beberapa saran yaitu :

1) BP2D Kota Malang hendaknya lebih memberikan pelatihan IT kepada beberapa pegawainya yang dirasa mampu. 


\section{REFORMASI}

ISSN 2088-7469 (Paper) ISSN 2407-6864 (Online)

Volume 8 Nomor 2 (2018)

2) peran pemimpin untukmemotivasi pegawai BP2D dengan memberikan reward dan punishmentserta memotivasi para pegawai untuk melakukan studi lanjut baik ke strata 1 maupun ke strata 2 dan strata 3.

\section{DAFTAR PUSTAKA}

Domai, Tjahjanulin. 2011. Sound Governance. Malang: UB Press

Hasibuan, Malayu S. P. 2012. Manajemen Sumber Daya Manusia. Jakarta: Bumi Aksara

Larasati, D. C. 2017. Evaluasi Program Inovasi "Sunset Policy" Di Kota Malang Guna Menurunkan Angka Tunggakan Pajak Bumi dan Bangunan Perkotaan, REFORMASI, 7 (1) : 21-30

Moleong, Lexy J. 2015. Metodologi Penelitian Kualitatif. Bandung: Rosdakarya.

Pahala, Mariot Siahaan. 2016. Pajak Daerah dan Retribusi Daerah. Depok: PT. Raja Grafindo Persada.

Pahala, Mariot Siahaan. 2013. Pajak Daerah dan Retribusi Daerah. Jakarta: Raja Grafindo Persada.

Sedarmayanti. 2016. Manajemen Sumber Daya Manusia. Bandung: RefikaAditama.

Subkhi, Akhmad. 2013. Pengantar Teori \& Perilaku Organisasi. Jakarta: Prestasi Pustakaraya.

Sugiyono. 2015. Memahami Penelitian Kualitatif. Bandung: CV. Alfabeta.

Suwatno. 2013. Manajemen SDM. Bandung: Alfabeta.

Undang-Undang Pemerintahan Daerah, 2015. Bandung: Fokusindo Mandiri

Undang-Undang Nomor 28 tahun 2009 tentang Pajak Daerah dan Retribusi 